\title{
Některé problémy a etické otázky spojené s pastorací lidís psychickým onemocněním
} Miroslav Škoda

V současnosti se stává pastorace lidí s psychickým onemocněním naléhavým úkolem především proto, že počet takto nemocných lidí trvale roste. ' Zmiňovaná pastorace má svá specifika, problémy a etické otázky, které vyvstávají hlavně v souvislosti s řešením těchto problémů. $V$ předkládaném příspěvku se chceme zaměřit na ty z nich, které podle nás podstatně ovlivňuji kvalitu pastorační práce s duševně nemocnými lidmi. Jsou to na jedné straně ve společnosti (farnosti) rozšîrené negativní předsudky vưči psychicky nemocným lidem (předsudky vưči jejich pobytu $v$ psychiatrické léčebně, vưči medikaci psychofarmaky aj.), na druhé straně je to v některých př́padech problém pastoračního pracovníka, který nemá či z podstaty věci ani nemưže mít dostatek potřebných informací o charakteru psychických obtíži duševně nemocného člověka či o historii jeho duchovního života. Tento nedostatek ztěžuje doprovázení a pomoc psychicky nemocnému v jeho obtížích.

Pro reflexi zmíněných problémů a hledání odpovědí na zkvalitnění práce v této oblasti pastorace bude nutné nejdřive vymezit pro náš záměr dưležité (základní) pojmy, především koho řadíme mezi tzv. psychicky nemocné lidi a kdo je to pastorační pracovník. Na základě tohoto rozlišení můžeme i specifikovat rovinu námi sledovaných problémů a s nimi spojené etické otázky. Záměrem tohoto článku je, alespoň v obecné rovině, poukázat na důležitost nejen odborné, ale i etické kompetence pastoračního pracovníka, aby jeho služba psychicky nemocným byla erudovaná a eticky ospravedlnitelná.

\section{Psychická nemoc - psychicky nemocný člověk - předsudky}

Pojem psychická (duševní) nemoc není snadné vymezit. Samotný pojem "nemoc" se často uvádí v protikladu k pojmům "normalita" a "zdraví". Za normalitu přitom považujeme projevy, které v daném kulturním okruhu nacházíme u většiny lidí. Zdraví je podle toho specifický případ normálního a má svou objektivní a subjektivní stránku. ${ }^{2}$

Sociologie někdy chápe nemoc jako specifickou deviaci. Na rozdíl od společenských deviací není následována negativními sankcemi, protože se od nich odlišuje kritériem osobní odpovědnosti. Nemoc se objevuje bez volního přispění nemocného. V tomto kontextu je role nemocného popsána T. Parsonem (1965) a rozpracována E. Freidsonem (1970) s důrazem na její čtyři rysy: „Za prvé je nemocný považován za nezodpovědného za vznik svého stavu a za neschopného odstranit ho svou vưlí. Za druhé je zproštěn svých dosavadních povinností. Za

\footnotetext{
1 V roce 2012 bylo v ambulantní péči léčeno 578413 lidí (v roce 2011 to bylo 556456 lidí) a v psychiatrických léčebnách bylo 40683 pacientů (v roce 2011 to bylo 40 754, ale v roce 2010 to bylo 39697 lidí). Celkem bylo v roce 2012 provedeno 2833944 psychiatrických vyšetření (v roce 2011 to bylo 2799199 vyšetření). Podle jednotlivých ukazatelů se tak jedná o meziroční nárůst $4 \%$ lidí léčených v ambulantní péči, pokles o 0,2\% pacientů v psychiatrických léčebnách a nárůst 1,2 \% všech psychiatrických vyšetření v roce 2012 proti roku 2011. Zpracováno podle: (C) ÚZIS ČR, 2012, Zdravotnická ročenka ČR 2012 (on-line), dostupné na: http:/ / www.uzis.cz/katalog/rocenky/zdravotnicka-rocenka-ceskerepubliky, citováno 17. 3. 2014 a podle @ ÚZIS ČR, 2012, Zdravotnická ročenka ČR 2011 (on-line), dostupné na: http:/ / www.uzis.cz/katalog/ rocenky/zdravotnicka-rocenka-ceske-republiky, citováno 17. 3. 2014.

2 Srov. Karel DUŠEK - Alena VEČEŘOVÁ-PROCHÁZKOVÁ, Diagnostika a terapie duševních poruch, Praha: Grada Publishing, 2010, s. $22-23$.
} 
třetí je nemocný povinen dávat najevo vědomí nežádoucnosti svého stavu a jeho přechodnost a konečně (za čtvrté) je povinen vyhledat odborníky a spolupracovat s nimi, nedojde-li ke spontánní úpravě." 3

Sociologií formulované specifické postavení nemoci vůči společenským deviacím předznamenává i specifické postavení duševní nemoci v rámci nemoci. Zatímco „u somatické nemoci jde o poruchy struktury a funkce orgánů, (...) u duševních nemocí (přirozeně s výjimkou organických) o nic podobného nejde “4 . Je proto obtížné určit, co je psychická nemoc i jakou metodou ji lze diagnostikovat. Alberto Bondolfi v této souvislosti připomíná: „Jediné, v čem jsme schopni se shodnout, je, že psychická nemoc může být i tam, kde nejsou prokazatelné organické př́ičiny, jako nakonec i v tom, že psychické poruchy nebo psychická nemoc mají rozličné podoby a stupně, které je velmi těžké rozlišit. " 5

Je to nakonec právě pojetí nemoci jako sociální kategorie, které umožňuje zařadit psychické poruchy do Mezinárodní klasifikace nemocí (dále MKN). Tato sociální kategorie je totiž „určená k označení stavu jedinců, o němž daná společnost předpokládá, že znemožňuje nositeli plnění obvyklých rolí, a který nemůže odstranit pouhým chtěním“ ${ }^{\text {" }}$. MKN pak představuje "seznam stavů majících společné právě uvedené předpoklady“7.

Výše nastíněné obtíže s definováním psychické nemoci, resp. stavu psychicky nemocného, odráží nakonec problematičnost $\mathrm{v}$ samotných předpokladech pastorační praxe s takto nemocnými lidmi a predikuje četná úskalí s ní spojená (viz níže). Problémem jsou např. lidé, kteří reálně trpí psychickým onemocněním, ale nevyhledají odbornou pomoc. Nikdo u nich nestanovil diagnózu. Tato skupina duševně nemocných může představovat velké riziko pro společnost. Mnohdy jsou takoví lidé nebezpeční i sobě, např. sebepoškozováním či suicidálním jednáním. Důvodem, proč nevyhledají při psychických obtížích pomoc psychiatra či psychologa, jsou mnohdy právě společensky rozšířené předsudky vưči tomuto postupu. Psychická nemoc bývá totiž dosud často považována za zahanbující. V mnoha případech je skutečnost jít na potrat společensky přijatelnější než návštěva psychiatra. Tato hluboká deformace ztěžuje situaci nejen nemocnému, ale především jeho nejbližším. I mezi křest’any existují v této záležitosti neospravedlnitelné „náboženské“ předsudky. Patří mezi ně např. přesvědčení, že za většinu psychických obtíží si může člověk sám. Je to podle nich důsledek jeho morálních selhání či nedostatečně žité víry. Zdravé víře se podle nich př́ičí i užívání psychofarmak. Tyto předsudky jsou bezesporu v rozporu s pojetím sociální role pacienta, resp. s jejími čtyřmi rysy, jak jsou popsány výše.

V praxi se můžeme setkat ale i s opačným problémem než s tím, který jsme dosud popsali. Za psychicky nemocné mohou být diagnostikováni i ti, kteří duševně nemocní být nemusí. Na vině je chybně určená diagnóza ze strany lékaře, což ovšem mưže být důsledek vlastního účelového jednání (simulace, agravace) „pacienta“. Za psychicky nemocného lze proto pod-

3 Karel CHROMÝ, Duševní nemoc. Sociologický a sociálněpsychologický pohled, Praha: Avicenum, 1990, s. 15-16.

4 Tamtéž, s. 19. Poznámka autora: S rozvojem lékařské vědy v oblasti diagnostiky se ukazuje, že velké množství psychických nemocí má svůj organický původ. Nemusí se jednat př́mo o poruchy orgánů jako celku. Na úrovni buněk však zde hrají svou roli genetické dispozice, biochemické procesy, neurobiologické jevy a neurotransmiterové přenosy informací aj.

5 Alberto BONDOLFI, Ethische Wertungen des Suizids im Laufe der Geschichte: Übertretung des Tötungverbots, Pathologie...?, In: Suizid...? Aus dem Schatten eines Tabus, ed. Hans-Balz PETER - Pascal MÖSLI, Zürich: TVZ, 2003, s. 45n.

6 Karel CHROMÝ, Duševní nemoc, s. 19.

7 Tamtéž.

8 Srov. Aleš OPATRNÝ, Pastorační péče v méně obvyklých situacích, Praha: Pastorační středisko sv. Vojtěcha při Arcibiskupství Pražském, 2005, s. 33 . 
mínečně považovat pouze toho, komu byla odborníkem stanovena diagnóza MKN-10. ${ }^{9}$ Často jsou tito lidé v ambulantní či ústavní péči lékařů - psychiatrů.

\section{Pastorace - pastorační pracovník - problém informovanosti}

Pojem "pastorace" či "pastorační péče" nemá u nás zcela přesné vymezení. Jako odrazový můstek $\mathrm{k}$ definici pastorační péče může pomoci popis realizačních úkolů církve, jak je chápe současná pastorální teologie. Tyto úkoly bývají vyjadřovány čtveřicí řeckých slov: kérygma (hlásání), diakonia (služba potřebným), leiturgia (bohoslužba, liturgie) a koinonia (vytváření a péče o společenství). Podrobnější cíle a hlavní zásady pastoračního jednání pak obsahuje definice Aleše Opatrného. Podle něho „pastorační péčí v širším slova smyslu rozumíme takové jednání $\mathrm{s}$ člověkem, ve kterém ho respektujeme $\mathrm{v}$ jeho jedinečnosti, přistupujeme $\mathrm{k}$ němu z pozice věřících křest'anů, doprovázíme ho v jeho obtížích, nemoci, utrpení či umírání a pomáháme mu k lidsky důstojnému zvládnutí jeho životní situace včetně smrti, a to na jemu dostupné úrovni víry s perspektivou jejího možného rozvoje ${ }^{\prime 10}$. V této definici jsou již zahrnuty podrobnější cíle a hlavní zásady pastoračního jednání (např. př́istup z pozice věřícího křest'ana či přristup na úrovni víry toho, kterému pomáhám).

Spolu s vymezením rozsahu či obsahu pastorační péče je nutné to samé učinit i ve vztahu k pojmu pastoračního pracovníka (pastorujícího). V minulosti byl subjektem pastorace především kněz. Přesto, že za pastýře ve specifickém slova smyslu je dosud v současném Kodexu kanonického práva (CIC) z roku 1983 (kán. 375 §1 a kán. 515 §1) považován biskup, resp. kněz, je zde zároveň formulován i podíl laikư ${ }^{11}$ na pastoračních úkolech. Ještě zřetelněji je toto očekávání aktivní účasti laiků na pastoraci formulováno v dokumentu Jana Pavla II. Christifideles laici. ${ }^{12}$ Zdůrazňuje se zde, že všichni pokřtění se mají podílet na realizačních úkolech církve.

V pastoraci psychicky nemocných není sociální status pastoračního pracovníka nevýznamnou skutečností. Do značné míry předurčuje možnosti, resp. kvalitu pastorační práce s psychicky nemocnými lidmi. ${ }^{13}$ Velkou výhodou a jistou nezbytností je pro pastoračního pracovníka na poli pastorace psychicky nemocných jeho minimálně nižší odborné vzdělání v oboru psychologie a psychiatrie (kurzy, psychoterapeutický výcvik apod.). ${ }^{14}$ Uschopňuje ho to $\mathrm{k}$ tomu, posoudit psychické problémy konkrétního člověka alespoň do té míry, aby byl schopen rozpoznat potřebu nasměrovat ho na př́islušné odborníky, kteří mu mohou poskytnout kvalifikovanou pomoc. ${ }^{15}$

\footnotetext{
9 ๑) ÚZIS ČR 2010-2014, MKN-10 Tabelární část (aktualizovaná druhá verze k 1. 1. 2013) s. 189-258. (on-line), dostupné na: http://www. uzis.cz/zpravy/aktualizace-mkn-10-platnosti-od-1-ledna-2013, citováno dne 21. 3. 2014. Více k problematice klasifikace duševních poruch lze nalézt v Petr SMOLÍK, Klasifikace duševních poruch, in: Psychiatrie, ed. Cyril HÖSCHL - Jan LIBIGER - Jaromír ŠVESTKA, Praha: TIGIS, 2002, s. 329-339.

10 Aleš OPATRNÝ, Pastoračni péče v méně obvyklých situacích, s. 9.

11 Pojem laik je sám o sobě víceznačný. Zde jsou jím označovány dvě skutečnosti současně: 1) Z hlediska církevního práva (CIC z roku 1983, kán. 207 § 1.) jsou laikové všichni křest́ané, kteří nepřijali svátost svěcení. 2) Druhou skutečností, kterou termín laik popisuje, je formální neodbornost v oboru klinické psychologie či psychiatrie.

12 Srov. JAN PAVEL II., Christifideles laici, 2. vyd., Praha: ZVON, 1996, čl. 23, s. 40-43.

13 Kněz může např. sloužit svátostmi.

14 U absolventů teologických fakult, kteří ve většině případů skládají státní závěrečnou zkoušku z psychologie, se tyto bazální znalosti dají předpokládat.

15 Pastorační péče o nemocné není jen záležitostí pastoračních pracovníků, ale také zdravotnických zařízení, která by měla spolupracovat $\mathrm{v}$ této oblasti s církvemi a náboženskými společnostmi. Jedná se totiž o uspokojení spirituálních potřeb člověka. Tyto spirituální potř̌eby jsou vlastní každému člověku, a nemusejí být nutně nábožensky tematizovány. Péče o ně patří k celkové péči o nemocného, a proto by na jejich uspokojení měla být zainteresována též zdravotnická zařízení. Blíže k tomu Aleš OPATRNÝ, Ti, kdo nemocné doprovázejí, in: Praktická teologie pro sociální pracouníky, ed. Michael MARTINEK a kol., Praha: JABOK, 2008, s. 145.
} 
Problémem pastoračního pracovníka při pastoraci psychicky nemocných lidí, který znesnadňuje účinnou pastorační péči, je nakonec vždy nedostatek informací o psychicky nemocném. Tyto informace lze přitom rozdělit do dvou kategorií: informace o zdravotním stavu pacienta a informace o historii duchovního života nemocného. Obzvlášt' citelně se tento deficit projevuje v prostředí psychiatrických léčeben, kde rovněž může pastorace probíhat.

Zákonná úprava chránící soukromí pacienta neumožňuje, aby informace o zdravotním stavu podával střední a nižší zdravotnický personál. Tyto informace, které jsou součástí lékařského tajemství, může prakticky podávat jen lékař, a to ještě za striktních podmínek, které stanovuje Zákon 372/2011 Sb., o zdravotních službách a podmínkách jejich poskytování. Hlavní z nich je výslovný souhlas (v písemné formě) pacienta o podávání informací o svém zdravotním stavu konkrétním osobám, které nejsou s nemocným v žádném příbuzenském vztahu. ${ }^{16}$ Bez tohoto souhlasu nesmí lékař podat informace pastorujícímu. Pastorační pracovník není v zákoně uveden jako osoba, která by měla automaticky právo na informace o nemocném, př́ípadně právo nahlížet do zdravotnické dokumentace. ${ }^{17}$ Pastorující je tak většinou odkázán na informace od samotného pacienta. Ty však často bývají vzhledem k jeho psychickému onemocnění zkreslené.

Informace o předchozím duchovním životě psychicky nemocného jsou rovněž důležité. Deficit těchto informací u pacientů s onemocněním, které doprovázejí bludy (např. schizofrenie), nebo u lidí trpících demencí se projevuje zvláště výrazně. Vnímání reality (včetně minulosti) těchto pacientů může být totiž velmi odlišné od normálního posuzování minulosti, jak jsme na ně zvyklí u zdravých lidí. Pokud má pastorující spolehlivé informace o předchozím plnohodnotném duchovním životě nemocného před propuknutím nemoci (tzn. jedná se o praktikujícího věřícího), může projevit větší shovívavost k zmateným postojům a prožitkům nemocného v současnosti. Ty nemusí být ani překážkou k udělení svátostí. Situace je však odlišná, pokud nemocný nikdy neznal skutečný význam hodnot, které svátosti zprostředkovávají. Zde se doporučuje posloužit nemocnému pastoračním rozhovorem a pomoci mu případně na cestě k Bohu.

\section{Některé etické otázky spojené s hodnocením psychicky nemocného a zásady př́ístupu k němu}

Pastorační práce s psychicky nemocnými lidmi v sobě zahrnuje také požadavek kladený na pastoračního pracovníka, aby dokázal adekvátně morálně hodnotit jednání a chování psychicky nemocného člověka. Za dané situace ovšem přísluší pastoračnímu pracovníkovi morálně hodnotit pouze nepatologické jevy, jako jsou např. skleslost, špatná nálada či smutek klienta, a zároveň ho smí v duchovním doprovázení vést $\mathrm{k}$ jejich odstranění či alespoň korekci. $\mathrm{V}$ př́padě afektivní poruchy, která může být u klienta doprovázena stejnými projevy jako v nepatolo-

16 Uvedené tvrzení se opírá o Zákon č. 372/2011 Sb., o zdravotních službách, § 33 odst. 1: „Pacient může při přijetí do péče určit osoby, které mohou být informovány o jeho zdravotním stavu, a současně může určit, zda tyto osoby mohou nahlížet do zdravotnické dokumentace o něm vedené nebo do jiných zápisů vztahujících se k jeho zdravotnímu stavu, pořizovat si výpisy nebo kopie těchto dokumentů a zda mohou v případech podle $\$ 34$ odst. 7 vyslovit souhlas nebo nesouhlas s poskytnutím zdravotních služeb. Pacient může určit osoby nebo vyslovit zákaz poskytovat informace o zdravotním stavu kterékoliv osobě kdykoliv po přijetí do péče, rovněž může určení osoby nebo vyslovení zákazu poskytovat informace o zdravotním stavu kdykoliv odvolat. Záznam o vyjádření pacienta je součástí zdravotnické dokumentace o něm vedené; záznam podepíše pacient a zdravotnický pracovník. Součástí záznamu je rovněž sdělení pacienta, jakým zpưsobem mohou být informace o jeho zdravotním stavu sdělovány."

17 V Zákoně č. 372/2011, o zdravotních službách, § 65 jsou uvedeny osoby, které smějí nahlížet do zdravotní dokumentace, případně z ní pořizovat výpisy či kopie. Duchovní, či pastorační pracovník nikde v tomto paragrafu uveden není. Navíc osoby, které smějí nahlížet do dokumentace podle tohoto paragrafu, jsou vázány mlčenlivostí. V opačném př́ipadě se dopouští správního deliktu podle $§ 117$ téhož zákona. Tento delikt je peněžitě sankcionován (porušení mlčenlivosti do výše 1000 000,- Kč; neoprávněné poskytnutí dokumentace do výše 500 000,- Kč). 
gických případech, není však morální hodnocení klienta, resp. jeho chování, ze strany pastoračního pracovníka zcela na místě. Afektivní porucha je totiž závažné psychické onemocnění a určení morální odpovědnosti je v takovýchto případech velmi problematické. ${ }^{18}$ Toto základní rozlišení, jakož i mnohá další, která je blíže specifikují, nelze při naplňování výše uvedeného požadavku opomenout.

Psychická nemoc se sice, jak bylo výše zdůrazněno, objevuje u nemocného většinou bez jeho volního přičinění, není tím však výslovně řečeno, že $\mathrm{v}$ jednotlivých případech nemůže být dotyčný do jisté míry za vznik a průběh své nemoci odpovědný. Toto tvrzení je možné opřít o tzv. modely duševních poruch, jak je formuluje současná psychiatrie. Jde o „zjednodušené abstrakce jednotlivých teorií či hypotéz, které se v současné nebo minulé psychiatrii uplatňovaly“ ${ }^{\prime 19}$. K. Chromý popisuje osm takovýchto modelů. ${ }^{20} \mathrm{~V}$ každém z nich je pacientova odpovědnost za psychický stav vnímána jinak. Z našeho úhlu pohledu je vhodné zmínit především dva z těchto modelůa, a to model lékařský a morální. Tyto modely nabízejí odlišné morální hodnocení jednání psychicky nemocného člověka.

V lékařském modelu, který patří v dnešní psychiatrii mezi nejvlivnější a nejrozšířenější a na jehož bázi nahlížíme psychickou nemoc i v tomto pojednání, se odpovědnost pacienta za nemoc více či méně vylučuje. Morální (behaviorální) model ${ }^{21}$ naopak s určitou mírou odpovědnosti přímo počítá, zejména $\mathrm{v}$ průběhu nemoci. Přesto se i v rámci tzv. lékařského modelu, pro který má jistý význam etiologie psychické nemoci (ačkoliv nemusí být vždy známa), připouští v jednotlivých případech osobní odpovědnost psychicky nemocného za svoji nemoc, zejména za její propuknutí. Jedná se především o případy, kdy si psychicky nemocný člověk mohl např. nezdravým způsobem života či experimentováním s drogami vytvořit spouštěcí mechanismus nemoci. „Proviněním“ může být i nepřiměřené se vystavování stresovým situacím, nevhodné psychosociální prostředí, ve kterém se člověk dobrovolně pohybuje, nebo v ojedinělých případech i jednání proti svému svědomí, které může způsobit nezvladatelnou úzkost aj.

Ve všech uváděných případech je nakonec při posuzování morální odpovědnosti pacienta za svou nemoc nutné reflektovat míru jeho svobody. Ta rozhoduje a spoluurčuje míru odpovědnosti za jeho celkový stav. Svobodou vůle nebo volby se zabývá i Helmut Weber. ${ }^{22}$ Zdůrazňuje, že ne vše je $v$ životě člověka předem stanovené, a proto svoboda vůle a volby v zásadě musí existovat. Na druhou stranu dodává, že jednotlivé danosti a ustanovení v lidském životě mohou sahat velmi daleko a prostor svobody je často jen nepatrný. Mnohotvárnost života může svobodu $\mathrm{v}$ jednání značně omezit a dokonce vyřadit. ${ }^{23} \mathrm{~V}$ jednotlivém případě může tato možnost zcela a dokonce po celý život chybět. Jako př́iklad uvádí právě těžké duševní onemocnění. ${ }^{24}$ I na základě tohoto tvrzení se lze oprávněně domnívat, že psychická onemocnění představují mnohdy velké omezení svobody vưle a volby, a tím míry odpovědnosti za jednání i za svůj zdravotní stav u psychicky nemocných pacientů. Nutné je též zohlednit při morálním posuzování odpovědnosti člověka za propuknutí nemoci skutečnost, že dotyčný jen

\footnotetext{
18 Srov. Aleš OPATRNÝ, Pastorační péče v méně obvyklých situacích, s. 82.

19 Karel CHROMÝ, Duševní nemoc, s. 27.

20 Názvy těchto modelů jsou: morální model, model lékařský či biomedicínský, psychoanalytický model, defektový či handicapový model, rodinný interakční model, sociální model, psychedelický model, konspirační model. Srov. Karel CHROMÝ, Duševní nemoc, s. 27-37.

21 V současnosti je podoba morálního modelu behaviorální. „Soudobá (behaviorální) verze modelu chápe (...) poruchu jako naučené dysfunkční chování. Mechanismus vzniku - na rozdíl od udržování - je nevýznamný a interpretace zbytečná. Náprava spočívá v odstranění nežádoucího chování pomocí pozitivních a negativních sankcí. (...) Společnost má právo bránit se před porušovateli norem, ale musí nabízet možnosti ke změně chování ve smyslu platných norem.“ Karel CHROMÝ, Duševní nemoc, s. 28.

22 Srov. Helmut WEBER, Všeobecná morální teologie, Praha: Zvon a Vyšehrad, 1998, s. 229-231.

23 Srov. tamtéž, s. 229.

24 Srov. tamtéž, s. 230.
} 
stěží odhaduje možné následky svého rizikového chování. Jestliže pacient neměl bez vlastního zavinění dostatek informací o tom, $\mathrm{k}$ čemu může jeho rizikové jednání vést, lze ho (alespoň částečně) dispenzovat od morální odpovědnosti za svou psychickou nemoc, kterou si tímto jednáním způsobil. Náležitá informovanost o psychických onemocněních a jejich spouštěcích mechanismech se $\mathrm{z}$ tohoto úhlu pohledu jeví jako naléhavý požadavek osvěty.

Při určení míry morální odpovědnosti psychicky nemocného člověka by měly být zohledněny i další skutečnosti (např. psychosociální prostředí v rodině, ve škole, na pracovišti), které ovlivňují chování a jednání pacienta před, ale i po propuknutí psychické nemoci. Za vlastní psychickou nemoc lze tedy na základě výše řečeného vinit samotného pacienta jen v omezené míre, pokud máme vůbec právo vynášet morální soudy nad těmito lidmi, kteří trpí a strádají svou nemocí.

Kvalitní a eticky ospravedlnitelnou pastorační péči o psychicky nemocného podmiňuje nejen jistá zdrženlivost v etickém hodnocení jeho jednání, ale i dodržování jistých zásad v př́istupu $\mathrm{k}$ němu. Tyto zásady lze rozdělit na obecné, které by měly být aplikovatelné $\mathrm{v}$ přístupu ke všem psychicky nemocným, a na zásady specifické, které lze aplikovat jen u jednotlivých typů duševních poruch. ${ }^{25}$

Jednou z nejobecnějších zásad přístupu k psychicky nemocnému je přijmout nemocného bezpodmínečně, bez předsudků, vnitřního odporu a odsuzování. ${ }^{26}$ To nemusí být v konkrétních př́ipadech snadné. Pokud to ale pastorující nedokáže, je lépe, když se pastoraci na tomto poli raději vyhne.

V oblasti života $z$ víry platí princip přiměřenosti a přijatelnosti. Platí to především pro praxi udělování svátostí a jiných náboženských úkonů, jakož i v udělování duchovních rad. Je třeba na tomto místě připomenout hlavní zásadu lékařské etiky, která latinsky zní Primum non nocere (= v první řadě neškodit). Právě nepřiměřenost v náboženské oblasti může psychicky nemocnému ublížit. Kritériem přiměřenosti je v těchto př́ípadech druh duševní poruchy a aktuální zdravotní stav nemocného. ${ }^{27} \mathrm{~K}$ tomu je nutno připočíst kompetenci pastoračního pracovníka rozlišit to, co v daném stavu psychicky nemocný člověk „může a nemůže, co mu v oblasti života z víry a z praxe zbožnosti prospívá a co škodí“ ${ }^{28}$. V tomto de facto „spočívá zásadní jádro dobré pastorační péče o nemocného (ostatně i o zdravého)“ ${ }^{29}$.

\section{Závěr}

Ambicí tohoto pojednání nebylo předložit vyčerpávajícím zpo̊sobem problematiku pastorační práce s psychicky nemocnými lidmi. Zaměřili jsme se pouze na dvě roviny problému. Jde o obecně rozšiřené předsudky vưči duševně nemocným a problém mnohdy nedostatečné informovanosti pastoračního pracovníka o skutečném stavu takto nemocného člověka. $\mathrm{V}$ obou případech se ukazuje jistá „bezmocnost“ pastoračního pracovníka dané skutečnosti změnit. Přesto mu to nemůže bránit v úsilí i za těchto podmínek poskytovat kvalitní pastorační péči psychicky nemocným lidem. Základním předpokladem k tomu se zdá být nejen jeho přiměře-

25 Můžeme si ale také zásady představit na kontinuální škále od nejobecnějších až k těm nejkonkrétnějším, které zohledňují konkrétního člověka v jeho jedinečnosti.

26 Srov. Aleš OPATRNÝ, Pastorační péče v méně obvyklých situacích, s. 34.

27 Srov. tamtéž, s. 82-87.

28 Tamtéž, s. 34.

29 Tamtéž. 
ná odborná erudice především v oblasti psychologie či psychiatrie, nýbrž také erudice etická, tj. jeho schopnost reflektovat s touto praxí spojené etické otázky.

Snažili jsme se zdůraznit, že pastorační pracovník je při práci s psychicky nemocnými lidmi konfrontován s řadou etických otázek, na které by měl umět citlivě a současně pravdivě reagovat. Základním požadavkem, který je při této práci na něho kladen, je respekt k psychicky nemocnému člověku. Od toho by se měl odvíjet $\mathrm{z}$ jeho strany přiměřený př́istup $\mathrm{k}$ němu odpovídající jeho situaci a možnostem. Jinými slovy řečeno, pastorační pracovník by měl citlivě vnímat potřeby psychicky nemocného člověka. Měl by umět dobře rozlišovat a správně hodnotit jeho chování, tzn. dostatečně zohledňovat míru jeho osobní svobody a odpovědnosti. Domníváme se, že právě zde je ukryt ústř̌ední rozměr kvalitní a eticky ospravedlnitelné pastorační práce s psychicky nemocnými lidmi.

\section{Některé problémy a etické otázky spojené s pastorací lidí s psychickým onemocněním}

Abstrakł Článek se zamýšlí nad kvalitou pastorační práce s psychicky nemocnými lidmi. Všímá si vybraných problémů této praxe a etických otázek s nimi spojených. Jedná se především o obecně rožšr̃ené předsudky vưči psychicky nemocným lidem a o mnohdy pro pastoračního pracovníka nedostupné informace o jejich zdravotním stavu či duchovním životě před onemocněním. Článek připomíná a zdưrazňuje obecné zásady přistupu pastorujicího $k$ takło nemocným lidem a etického hodnocení jejich jednání. Vưči psychicky nemocným lidem se vyžaduje pastorační prístup, který je odborně erudovaný a eticky ospravedlnitelný.

Klíčová slova pastorace, etika, psychická nemoc, psychicky nemocný člověk, předsudky, informovanost 